Moderation and the primary school context

Dr Paul Adams

Room LH208

Lord Hope Building

School of Education

Faculty of Humanities and Social Sciences

University of Strathclyde

141 St James Road

Glasgow

G4 OLT

Tel: +44 (0) 1414448078

Email: paul.adams@strath.ac.uk

Miss Jemima Anderson

Glasgow City Council

20 Alyth Crescent

Glasgow

G76 8PD

Email: jemimaanderson@hotmail.com 


\title{
Moderation and the primary school context
}

\begin{abstract}
This study presents an examination of the enactment of moderation in a Scottish primary school. The study investigated how an individual school made sense of moderation. Documentary evidence was gathered providing an in-depth understanding of both moderation and the wider context of the school. Audio recordings of three moderation meetings provided data on moderation enactment. Unstructured, semi-structured and focus group interviews captured the views of all participants involved in moderation. Moderation was viewed positively, understood as a social process enhancing collegiality and curriculum improvement. Finally, a typology for moderation is proposed.
\end{abstract}


Moderation forms an important part of education and its evolving rationale is representative of how policy has changed over the last 30 years; current predilections within the performative era position moderation as a means to verify educational activities for external audit. Whilst the mechanisms by which this occurs differ from state to state for many the focus is on moderation as part of national, externally mandated tests. Importantly, moderation also seeks to develop professional dialogue and debate underpinned by the belief that "educational change depends on what teachers do and think" (Fullan, 2001, p. 115).

Whilst research into moderation is not extensive, there have been a number of largescale, mixed methods studies, which claim generalisability to drive system reform efforts (cf. Hayward et al., 2012; Klenowski, 2013a). Notably, though, research is often sympathetic to a standards-based model and seeks to develop moderation as a workable process in the drive to 'raise standards' (Black, Harrison, Hodgen, Marshall and Serrett, 2010; Harlen, 2004). Accordingly, Harlen (2004) recommends further research into moderation, in particular with individual teachers and schools; Reid (2007, p. 133) concurs stating, "the process of local moderation is relatively under-researched". This lack of research is salient at a time when pressure on schools to act collegially grows but where space to do so is shrinking. For example, in Scotland, where the professional nature of moderation is lauded, the view that "schools and staff should ensure time for professional dialogue and support the development of staff confidence and professional trust in teachers" (Scottish Government, 2013 , p. 6 ) is offset by repeated calls to reduce teacher workload. Kay Barnett, convener of the Education Institute of Scotland [EIS] education committee, asserts that moderation should not "simply become a tick-box exercise [...] local 
authorities will be working on how to take it forward [...] time spent on forward plans and reporting will impact on time available" (EIS, 2012, pp. 1-2). There are tensions, then, arising from change processes and competing demands on teachers' time.

This paper is premised on the idea that there is a pressing need for teachers, researchers and policy makers to gain an "increasingly accurate approximation of reality" (Sprague, 2010, p. 85) of moderation rooted in a well-developed understanding of the context in which it is situated. The focus for the paper is moderation in Scotland: its enactment in one, local authority primary school where the study was the teachers and management team in the "bounded case" of one locale (Stake, 1995, p. 2). The research focuses on the micro level of policy enactment.

\section{The issue: moderation in Scotland}

For the purposes of this paper, and in keeping with Scottish orientations, moderation is defined as "a process involving teachers in discussion and debate about their interpretations of the quality of assessed work" (Klenowksi \& Wyatt-Smith, 2014, p. 74). In Scotland, previous policy advocated the use of external moderation through national tests. However, "in the climate of performativity that characterized the 1990s, what happened in Scottish schools was very different from policy intentions": tests drove teaching and the curriculum narrowed (Hayward, 2007, p. 255). A key driver for change, which led to changed assessment policy, was the desire to better align learning and accountability by ending external testing and introducing teacher moderation into primary schools. The Assessment is for Learning (AifL) (cf. Young, 2005) programme was pivotal in bridging the policy gap, as around one third of 
projects developed moderation and the programme reconstructed "teachers... as active learners, rather than the traditional view of teachers as passive conduits of policy" (Hayward, 2004, p. 403). In September 2009, Assessment for Curriculum for Excellence (CfE): Strategic Vision and Key Principles communicated four fundamental principles for assessment policy in CfE including a focus on breadth and depth of learning as well as "a greater focus on skills development" (Scottish Government, 2009a, p. 4). With the concomitant publication of Building the Curriculum 4; Skills for Learning, Life and Work (Scottish Government, 2009), there was the clear framing of a paradigm link between learning and the economy. This bolstered the proposition put forward in Building the Curriculum 3; A Framework for Learning and Teaching: "every child and young person is entitled to develop skills for learning, skills for life and skills for work, with a continuous focus on literacy and numeracy and health and wellbeing" (Scottish Government, 2008, p. 15).

At the time of the research, Scottish government policy on assessment was outlined in Building the Curriculum 5 (BtC5) (Scottish Government, 2011), an explicitly "standards-referenced assessment policy" (Adie, 2013a, p. 2) in which teacher professional judgement, developed and assured through moderation, is pivotal. BtC5 defines moderation as "the term used to describe approaches for arriving at a shared understanding of standards and expectations for the broad general education" (Scottish Government, 2011, p. 35). BtC5 also states, "moderation helps to raise standards and expectations" (Scottish Government, 2010, p. 36) However no evidence is provided to support this 'causal assumption'. 
Stated from the outset of BtC5 is the need to create a workforce that can meet the demands of the 'knowledge economy'. 'High standards' will "take account of international benchmarks" whilst "robust nationally benchmarked standards" will provide "confidence" (Scottish Government, 2010, p. 1). BtC5 communicates what moderation is and highlights aspirations for what it can achieve. The BtC5 ancillary document Quality Assurance and Moderation, offers the most extended but also most precise definition of moderation whereby teachers are required to:

1. plan learning, teaching and assessment;

2. check that assessment tasks and activities provide learners with fair and valid opportunities to meet the standards and expectations before assessments are used;

3. sample evidence from learners' work and review teachers' judgements;

4. agree strengths in learners' performances and next steps in learning; and,

5. provide feedback on teachers' judgements to inform improvements in practices.

As well as this checklist, it goes on to say:

Teachers involved in developing their assessment approaches through participation in moderation activities is a highly effective form of professional development. (Scottish Government, 2010, p. 3)

Scottish policy therefore conceives of moderation as social, enacted for the dual purpose of accountability and professional learning. However, not prescribed are the 'practicalities of enactment' in particular how often activities should take place, what exactly should be moderated and how this should be done. According to Hayward et 
al. (2012, p. 65) the practicalities of enactment have dominated local discourse and led to a patchy implementation across local authorities.

\section{Moderation: conceptual issues}

Moderation is located in the wider context of the social, economic, technological and cultural forces of globalisation and "the increasing colonisation of education policy by economic policy imperatives" (Ball, 2008, p. 39). The 21st century skills agenda as asserted by both the World Bank (WB) (2010) and the Organisation for Economic Cooperation and Development (OECD) (2012) strengthens the link between learning, schooling and work. Here, the "new concept of the ideal person" (Tatto, 2007 , p. 15) is one armed with a standardised set of 'skills' which will enable one to compete in the marketplace. Furthermore, neo-liberal capitalism has become a dominant influence on education with its agenda of management systems, performance, accountability and measurement and the increasing marketisation of education globally (Ball 2008; Lingard, Martino, \& Rezai-Rashti, 2013; Ozga, 2012). The commodification of education embodied in the certification of knowledge through high stakes national and international assessment has underpinned the rise of the 'knowledge economy' (Bereiter, 2002; Broadfoot, 1996; Olsen \& Peters, 2005; Adie, $2013 b)$. For this reason, the 'accountability agenda' is particularly prevalent in assessment discourses. In particular, the quality, quantity and nature of student certification, both at the micro level of individual schools, the meso level of local authorities and the macro level of nation states (Priestley \& Sinnema, 2014) comes to the fore. The use of assessment data for the purpose of accountability is often viewed diametrically: as a source of control and surveillance; as forcing malformation of character (e.g. cheating); as encouraging 'teaching to the test' (Ball, 2015; 
Broadfoot, 1996; Gipps, 2012; Harlen, 2007); as engendering the 'datafication' of education (Lingard, Martino, \& Rezai-Rashti, 2013; Roberts-Holmes, 2014); and, as 'governing by numbers' (Ozga, 2009). On the other hand, there have been attempts to reconcile accountability and humanistic educational purposes and drive forward change in the nature of assessment. For example, Datnow argues for "data-informed leadership” (2014, p. 12); 'intelligent accountability' systems which trust in professional judgement (Klenowski \&Wyatt-Smith, 2014; Murray, 2014; O’Neill, 2013); or the certification of skills and competencies that go beyond testing (Harlen, 2007; Gipps, 2012; Klenowski \&Wyatt-Smith, 2014; Wiliam, 2011). This sets the scene for the growth of moderation. The rise of a 'skills' and 'standards' agenda, a wider and more equitable conception of assessment, the use of a wider range of sources of evidence to drive educational decision making, the fostering of trust in teacher professional judgement; and, the growth of teacher and learner agency are all key drivers in the development of moderation, and in particular social moderation, in assessment systems.

From the literature, it is clear that moderation takes on particular meanings within educational assessment and from this three main categories can be discerned: external moderation; statistical moderation; and, social, also known as consensual or group, moderation (Wilson, 1992; Linn, 1993). Statistical moderation, the comparison of pupil assessment scores across institutions, is least written about whereas external moderation, where standards, rubrics, cross marking or tests are used to ensure consistency of judgement across individuals and institutions, is most prevalent. For example, Meadmore (1995) applies a Foucaldian lens and posits that a standards-based system compiles a body of evidence in order to judge the 
performance of an individual child. Ultimately this is used as a form of governance as the child comes to be represented by "a web of texts" (1995, p. 16). Thus, 'teaching to the standards' becomes indistinguishable from 'teaching to the test'. Hume \& Coll (2009, p. 287) concur, describing this phenomenon as "assessment as learning".

Conversely, social moderation, the focus of this paper, is the process whereby consistency of teacher judgement is ensured through collaborative working, either face to face (Wilson, 1992; Maxwell, 2002) or online (Adie, 2013a), within a single school, or between schools. Wilson (1992) and Taylor (1994), chart the movement of education systems from a paradigm of normative state measurement and control, to a criterion and standards-based system where space exists for greater teacher control of assessment. Such moves question underlying epistemologies and therefore the legitimacy of the measurement model. The contrary suggestion is that if standards are explicit, and learning, teaching and assessment aligned, learners have greater chance of success. Sadler (1992) draws on Habermas' concept of a 'legitimation crisis' to explain both the rise of moderation in standards-based assessment systems (Habermas, 1975) and the rise in forms of moderation which seek to secure legitimacy for a system in which judgements about learners are not purely based on episodic measurements.

Whilst critical theory dominated initially, the drive to grow moderation as an enacted practice has resulted in a far larger body of recent interpretivist research sharing a common ontology of moderation as a socially constructed and socially situated practice. The theoretical lens, which most frequently informs recent thinking, is the work of Lave \& Wenger (1991) and Wenger (1998). This posits that teachers 
engaged in moderation form a 'community of practice' in which they develop their assessment judgement and that social moderation by its nature embodies sociocultural theories of learning (Adie 2013a; Hipkins \& Robertson, 2011; Klenowski \& Wyatt-Smith, 2014).

More recently, moderation literature has coalesced around a bifurcation of either accountability or professional learning. Writers such as Klenowski and Wyatt-Smith (2014), Harlen (2007) and Maxwell (2002) note the ways in which moderation can be employed as a form of accountability in relation to ensuring valid, reliable and accurate teacher professional judgement, or, as a form of collegiate professional learning with the potential to alter what teachers do with regards to learning, teaching and assessment. Such functioning seeks to provide either "quality assurance" or "quality control" of learning, teaching and assessment, with the central purpose being to align the "judgements of different teachers" both within schools and between schools (Harlen, 2007, p. 20-21); the dichotomy is one of enabling accountability or improvement (Maxwell, 2002). Smaill (2013, p. 250) argues that the drive for accountability pushes professional learning into the category of moderation "byproduct" rather than "goal" and like many authors in the research field argues for professional learning to be the main aim of social moderation. Whether accountability or professional learning is the main driver for moderation's enactment depends on the values underpinning the assessment system and the low or high stakes nature of the individual localities in which it is developed. Maxwell suggests the greater the "public visibility and status" a judgement holds, the greater the need for accountability (2002, p. 1). 
To engage in moderation is to engage in a form of deliberation that is bifurcated between, on the one hand, distant, measure-based systems, or, on the other, interpersonal, socially oriented processes. Indeed, the former may offer a clearer and more robust way of determining comparisons. Importantly, facets of teachers' judgement have been isolated for positivist research scrutiny where teacher judgement is measured for accuracy and consistency (Gill and Bramley, 2013; Heldsinger and Humphry, 2013; MacCann and Stanley, 2010). Central to this idea of such a positivist approach is comparison, which has yielded some valuable information about particular issues such as consistency. However, in this orientation, the phenomena compared are treated as unproblematic; that standards, etc. are social constructions related to the social world of actors in the moderation process is ignored. Indeed, a number of studies and research reviews have found that teacher judgement, despite shared criteria or standards, is inconsistent across assessors, and is therefore potentially unreliable, particularly as a summative assessment measure (Bloxham, 2009; Brookhart, 2013; Hay \& Macdonald, 2008). Brookhart (2013) recommends further research into how teachers make judgements about performance suggesting latent beliefs about pupils compromise validity. Harlen (2004) and Black, Harrison, Hodgen, Marshall \& Serret (2010) suggest five slightly different criteria for improving the reliability and validity of teacher judgement believing that time invested in teacher learning can lead to improvement. Occupying an optimistic stance on teacher judgment, Collins, Reiss \& Stobart (2010) use a large-scale, mixed methods approach (600 respondents) to gather data on the removal of high stakes testing in Wales in favour of teacher judgement. Their main finding was a positive impact on teaching, learning \& curriculum. This agrees with the findings of Klenowski \& Wyatt-Smith (2012) who chart the impact of high-stakes 
testing in Queensland. They cite the unreliability of external testing programmes as evidence for investment in teacher learning with a view to securing greater alignment between learning, teaching and assessment. In agreement, Hayward et al. (2012, p. 87) argue for professional development to increase teachers' "assessment literacy" including the use of "professional advisors". Presenting a compromise, Allal (2013) perceives transparency and dependability of teacher judgement, alongside the reliability and validity of external testing, to be complementary goals within an assessment system.

More recently, and designed to inform the enactment of moderation, Scottish assessment guidance has focussed on exemplifying "achievement of a curriculum level" and "assessing progress and achievement in significant aspects of learning" (Educationscotland.gov.uk, 2015). National policy has intensified in the last 5 years, which Education Scotland, the national policy body, advises is "designed to develop understanding" (Educationscotland.gov.uk, 2015). However, this arguably functions on an ideological level, to ensure "the aims of government become assimilated more widely through a form of discourse capture" (Gillies, 2008, p. 420). What is not yet available, which our research seeks to address, is a picture of how individual schools make sense of this research and policy landscape, within the constraints of their particular context, uncovering how have they understood and enacted moderation and how this aligns with current Scottish policy. This paper offers some insight into this.

\section{Methodology}


The methodology employed here is a case study approach where the school is the case and moderation the issue (Stake, 1995, p. 2). A case study methodology was used to gain a thorough understanding of a singular context. The school, as was the case in all primary schools in Scotland, had been asked, through national guidelines, to embed moderation as part of its professional activities (Stake, 1995, p. 4). It was a rural primary school located in the West of Scotland with 104 children working in 6 classes, including composite classes, from primary 1 to 7 (ages 5 to 12). The Scottish Index of Multiple Deprivation (SIMD) provides a ranking of areas across Scotland from one (most deprived) to 6505 (least deprived). According to the Scottish Government, the school was located in a mid-range area with an SIMD score of 4204 (www.Gov.scot, 2015).

The conceptual framework described in figure 1 guided the research. The researcher used both propositional knowledge, in the form of factors explored in the existing literature, and tacit knowledge of schools and the moderation issue (c.f. Lincoln and Guba, 1985, p. 40). The research did not attempt generalisability or comparability but rather sought to observe, describe and interpret moderation in situ (c.f. Bassey, 1999, p. 44).

The above literature presents a tension between moderation for accountability and moderation for professional learning. As such matters impact on the work of schools and individual teachers, a case can be made for micro-level research. However, the interpretive and exploratory nature of this inquiry necessitated openness to the possibility of other tensions and themes emerging which were not considered. The investigation therefore required questions that would provoke open-ended inquiry 
and "inductive theorizing"; "making sense" of the data after it has been gathered and not forming pre-judgments (Gillham, 2000a, p. 7).

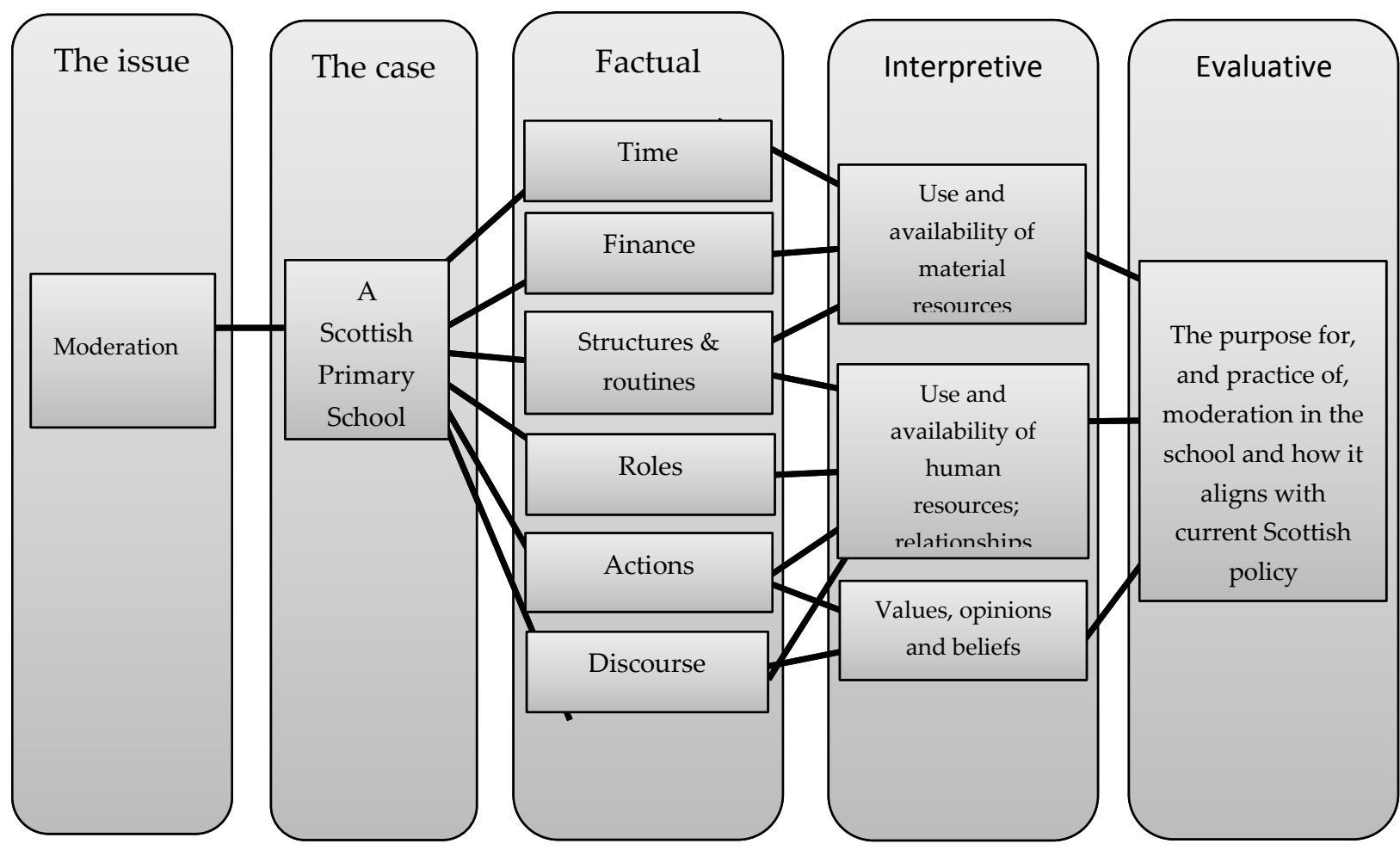

Figure 1 - The conceptual Framework for a Singular Case Study

The research questions were:

1. How is moderation understood in one primary school?

2. How is moderation enacted in one primary school?

3. To what extent is/are the purpose/s of moderation realised in practice in one primary school?

The population for this study was six fully qualified teachers including a principal teacher, one newly qualified teacher, one head teacher and one Local Authority Quality Improvement Officer (QIO). Table 2 describes this in more detail. 


\begin{tabular}{|l|l|}
\hline \multicolumn{1}{|c|}{ Participant } & \multicolumn{1}{c|}{ Role } \\
\hline Participant $1^{1}$ & Principal Teacher \\
\hline Participant 2 & Teacher \\
\hline Participant 3 & Teacher \\
\hline Participant 4 & Newly Qualified Teacher \\
\hline Participant 5 & Teacher \\
\hline Participant 6 & Student Teacher \\
\hline Participant 7 & Teacher and Moderation Facilitator \\
\hline Participant 8 & Teacher \\
\hline QIO & Quality Improvement Officer \\
\hline HT & Head Teacher \\
\hline
\end{tabular}

Table 2: Participant details

The research sought to create "new meanings" and "connect [the schools' moderation process] with better known things" (Stake, 1995, p. 97). The researcher engaged in both "direct interpretation" of both "individual instances" and "aggregations of instances" which Stake suggests can be discussed "as a class" (1995, p. 4). Whilst data were gathered 'factually' about each individual moderation meeting, the researcher reflected on the data extracted so that they could be discussed as a class.

\section{Methods}

\footnotetext{
${ }^{1}$ The principal teacher is referred to as a teacher in the data.

${ }^{2}$ The student teacher participated in one moderation meeting, but no data was extracted from her contributions as she took an observing role.
} 
Qualitative methods were selected. These allowed the researcher to capture a detailed picture from the perspective of all participants (Kumar, 2005). Documentary analysis 'set the scene', then:

- an initial, unstructured interview with the head teacher. The use of unstructured interviews can facilitate relationship building and flow like "natural conversation" (Gillham, 2000a, p. 6). As the head teacher was the leader and manager of the school, an unstructured interview at the outset enabled the researcher to build trust with a key informant.

- a telephone, unstructured interview with the QIO;

- As case-study research, "always involves the study of an instance in action" (Adelman, Jenkins \& Kemmis, 1980, p. 49), the researcher audio recorded three moderation meetings over a period of three months. Audio recording allowed the researcher to sit on the side-lines, minimizing any intrusion and the possibility of the Hawthorne effect (Newby, 2010). Each moderation meeting lasted approximately one and a half hours;

- A focus group interview with moderating teachers was the final piece of data gathered. The interview was responsive to the initial findings of the data and gathered the views of teaching staff about key factors relating to moderation. 70). Staff felt more comfortable interviewed as a group. The focus group interview lasted 40 minutes.

- The research involved one, final semi-structured interview with the head teacher. This allowed the head teacher to respond to initial findings of the data, and ensure the fullest picture possible of the case, what Lincoln \& Guba (1985) regard as triangulation through the selection of multiple methods of data gathering over time. 


\section{Data analysis}

Data gathering, analysis and conclusion-making ran concomitantly from the outset. A set analytic strategy was followed:

1. verbatim transcription of recordings and the summarising of documentary evidence. All transcripts were sent to participants to ensure accuracy. The data was descriptively coded initially using the comments facility of Microsoft Word. Once the descriptive codes were identified, these were then inserted into a table to code thematically;

2. the production of a document summary form to enable the identification of the main themes and patterns in the documentary data gathered;

3. the application of an initial descriptive code to the data;

4. the application of a second thematic code to the data and the extraction of overarching themes. The code was developed as the central themes and patterns of the data emerged.

Time was spent with each participant to ensure that data gathered accurately reflected that which they had said and to ensure that meaning was correctly inferred. The research was governed by the University of Strathclyde's Code of Practice on Investigations Involving Human Beings (2013).

\section{Results}

School documentation indicated that moderation was introduced to the school by the head teacher as a development priority in the Standards and Quality Report for 2010-11. This report contextualises moderation with a range of wider educational 
policies and initiative of the time such as Assessment is for Learning and coherence between planning, learning, teaching and assessment. Moderation at this time was attainment driven, unsurprising given the policy agenda of the curriculum of the time. The QIO agreed with this: her view was that moderation was introduced to the local authority as a quality assurance process to which schools were subject. It was: "that kind of model whereby standards were verified and schools were challenged...it was a wee bit inspectorial" (QIO). The head teacher confirmed that until 2012 moderation was not a 'within' school process but was used to quality assure the marking of pupils' writing:

but in my experience, and definitely within [the local authority], moderation meant once a year, getting together with staff from other schools and looking at pieces of kids writing, and saying why is this a level $E, F$ or post-CfE, why is this secure second level or secure first level. And that was the case right up until the time we were involved with [a neighbouring local authority] back in 2012-13. (Head teacher)

Over time, this view changed and the school came to view moderation as enabling an understanding of locally described 'standards': to be raising attainment in writing; to be a process that involved learners; and as a whole school endeavour. A member of the teaching staff was appointed as moderation facilitator.

Professional dialogue and moderation has led to common understanding of the high standards we have for attainment in writing, ensuring that teachers and pupils are clear as to how to improve. This has led to high standards of written work across the school. (School Standards and Quality Report, 20122013) 
In the 2013-14 Standards and Quality Report, the understanding of moderation shifts again: "moderated projects: staff at the school have developed a model for moderation" (HT). Moderation, initially 'introduced' to staff, was shifting to a concept being understood by staff as a 'project' and collegiate 'model'. A direct and close relationship between national policy and moderation practice in the school seems evident. Shown below, the school moderation process, which forms current school guidance on moderation, begins with consultation of BtC5. It is a nine stage social process involving collaboration of all staff.

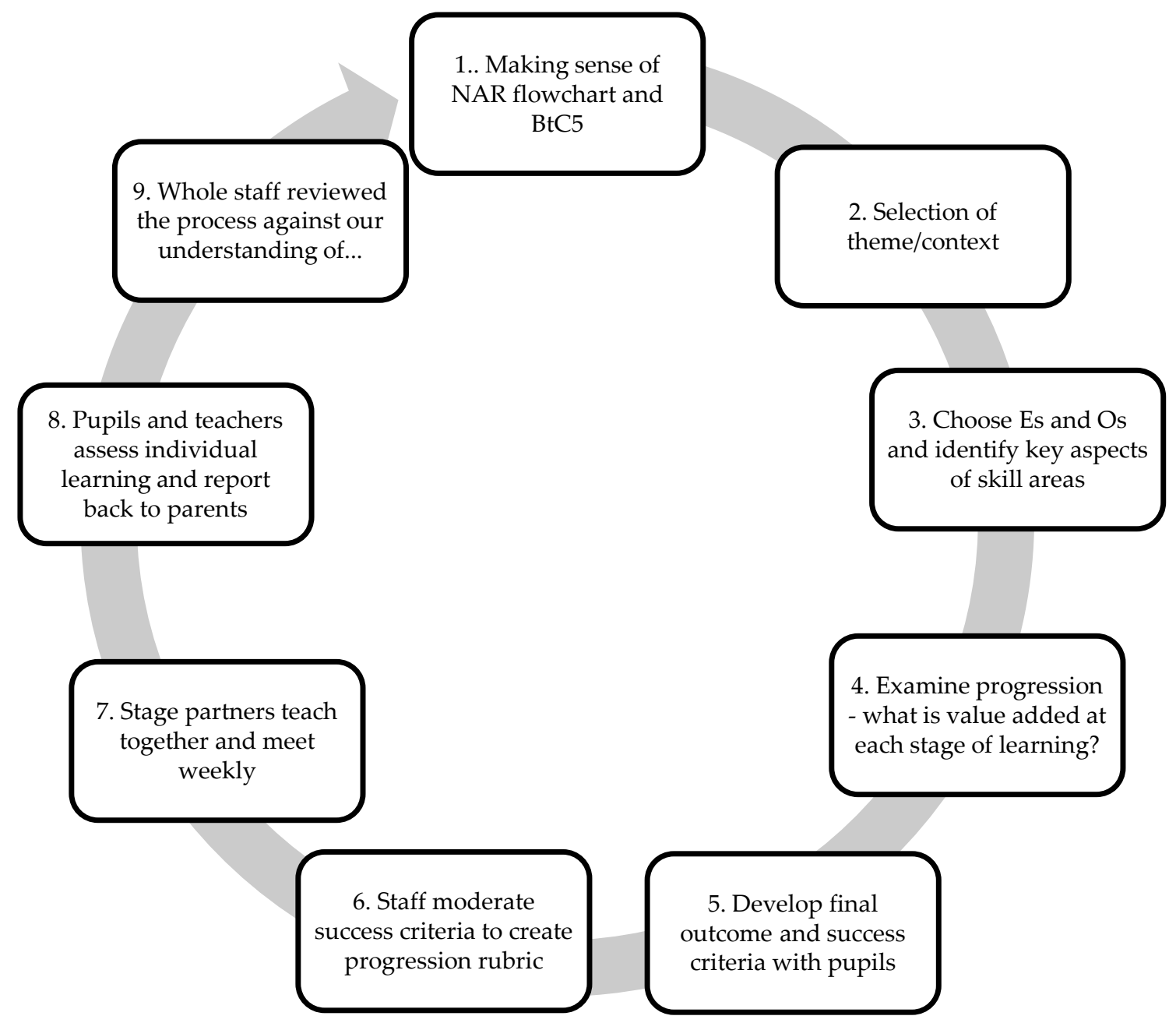

Figure 2: The School's Nine Stage Moderation Process (graphic authors' own, text extracted from the original school document) 
What became evident was that moderation was enacted in the workplace through a spoken rather than written discourse. Indeed, the moderation process outlined in Figure 2 above is the only documentation that directly refers to how moderation should be enacted in the school. Similarly, the interview data showed that moderation was enacted around themes, (enterprise and leadership), and discrete curriculum areas with a focus on skills. Moderation was interchangeably referred to as 'doing a project' or 'following the process'. The thematic focus for moderation has been decided by the head teacher who, as participant 1 noted, "looked for the skills that maybe weren't being covered or that we needed to make sure we were covering in curriculum areas".

The school used a 'core skills' document from another local authority to develop a locally produced version. Point 3 in the school moderation process identifies that skills and skills progression are embedded in the school's understanding of moderation. This shift from understanding 'moderation as external' to 'moderation as social' was incremental. Understanding of moderation within the school was influenced by the local authority through the 'training' of moderation facilitators. This latter idea came from an Education Scotland development officer who was working closely with the QIO: it was "her baby" that she was taking forward, "working in real partnership". According to the QIO, the moderation facilitator at the school "took this on right from the word go" and "is someone we have used as an example of what can happen, what can be done". The head teacher and participant 5 stated that the moderation process at the school has been influenced by a cross-authority project funded by Education Scotland which coincided with the first year of their 'within school' moderation process. 
What becomes apparent is that the timing of professional development for teachers, in particular the moderation facilitator, was an important variable in developing an understanding of moderation in the school. The interview data indicates that all participants understood moderation to be a developing practice within the school and one that requires leadership. The school constructed their own understanding of moderation:

It's got to work for us...there is no point in someone telling us this is how you have to do this. (Participant 2)

The need for moderation to be led, directed and supported was confirmed further by the teachers:

At times we needed the head teachers' vision and someone to drive it forward and to give the time and resources; you need that level of management. (Participant 1)

Whilst the teachers understood moderation as a process to be 'led', they also understood it to be a process over which they had 'ownership' as a whole school. The teaching staff and the head teacher believed moderation had increased the amount and the nature of collaborative working in the school, with the head teacher stating that moderation had brought about "a whole school understanding". Participants understood planning to be an essential element of moderation. The head teacher stated that the moderation process was "really planning intensive". Additionally, the teachers made a number of positive comments about joint planning as an element of moderation: 
You are sharing your ideas and actually it cut down on the planning time....before we were working in isolation. (Participant 5)

You don't feel alone with your planning to do. (Participant 2)

Data also indicated that all participants understood moderation to be important with regard to developing an understanding of the curriculum and in particular, skills progression from early to third level of the curriculum. The head teacher commented, "we wanted to develop a progression of skills, in terms of life, learning and work" whilst participant 1 understood moderation as enabling the "breaking down of the skills to an appropriate level for my wee ones" and that the teachers "would see the progression as they worked together".

Data indicated that teaching staff came to the planning stage of the moderation process informed by professional learning about the 'theme' to be moderated. As the head teacher indicated, "we weren't just making it up, we were researching". Moderation was seen as an opportunity for professional development in relation to the curriculum. Staff were judged by the head teacher to have moved "together as a team" in a collaborative way as a means to establish shared professional learning and ways of working. Staff looked at research on adult learning cycles, as moderation moved staff out of their "comfort zone" $(\mathrm{HT})$. However, teachers stated only positive comments about the enactment of moderation as a collegiate process. The moderation facilitator stated, "we supported each other with going through the process. We all took it together as a staff in the right direction". Participant 3 was 
clear: "well we have had times where we planned together even though we don't have to [laughs] the three of us will just sit down and plan".

This collaborative process was evident in the moderation meetings. Here the enactment of moderation followed the nine-stage process. The head teacher led these meetings, and kept the discussion focussed by giving instructions and time limits. However, despite the direct instruction from above, all felt able to disagree and challenge each other.

When making judgements about learners the discussions centred on individual children and evidence of their progress in relation to their prior achievement. A progression rubric was used to assess learners working in multi-age groups; children were not assessed according to their class 'norm'.

In terms of what we have spoken about a lot in terms of the progression rubric and it not being P5, P6, P7, you can see that with a P5 working at what you would expect of a P7 but they all fit into the rubric somewhere, it doesn't matter what stage they are at (Participant 7).

Data from the first meeting indicates that deciding upon the experiences and outcomes to be moderated took time: 40 minutes of the one hour and 30 minute meeting. The word 'standard' is not used by participants in any of the transcribed data. We can deduce that staff are using learning intentions (LI) and success criteria (SC) to frame conversations around expectations and the achievement of learners for selected experiences and outcomes (Es and Os). 
Two teachers suggested that the tracking document which monitors coverage of the Es and Os would be a more reliable way of selecting what is to be moderated. We can ascertain from this that the moderation process itself is under review and teachers feel able to make suggestions for improvement; in this case, regarding use of time and the alignment of moderation with curriculum coverage.

Additionally, the evidence used for making judgements in the final moderation session was not agreed prior to the meeting. Discussion in the meeting generated the moderation agenda discourse.

HT: I can see you all have in front of you your evidence with your LI rubric and your SC rubric, with the SC you got from the children, and you selected the key SC that you want to be assessed, yes? So what have you brought with you in terms of assessment sheets? Have you got a sample? So I guess the...is it possible that everyone has a top, middle and a bottom? Participant 1 and 2: We just brought one.

Participant 3: I have brought a P3 and P4 but the SC is slightly different but I didn't differentiate across P3 and P4.

Teachers presented a narrative account of selected children's learning journeys. Peer questions were teasing out more information about these. Discussion of the evidence of learning was summative in that the project was completed at this point, and teachers arrived at the final meeting with assessment judgements made. In this latter regard, the meeting served to confirm judgements. 
What was notable here was the fact that the pupils were involved in the creation of the success criteria against which they were judged. This was a collegial approach, not only between teachers; this collegiality extended to the pupils as well. Engaging learners in co-construction of the success criteria for the moderated learning intentions was viewed as a vital element.

"we were determined that children would be involved in designing the final outcome [of the moderation project] and also defining the success criteria". $(\mathrm{HT})$

Teachers held the children's contribution to the moderation process in high regard "I think that mine [the class] are better at writing SC than I am...I was like 'what'!" (Participant 7)

"it quite astounds me sometimes what they will actually come out with" (Participant 1).

Teachers also felt that this involvement ensured children were more focused in their learning "it is giving them ownership but its keeping them constantly focussed on what they need to do" and offered them personalisation and choice "especially the kind of personalisation and choice, that's made a difference. Whereas before you know I would talk to them about what they were going to do and then I would do what I planned anyway" (Participant 5).

But moderation was also being enacted around 'standards' in the form of learning intentions and success criteria: 
what we wanted them to be able to do is the learning intentions... and the specific skills, knowledge and abilities that underpin it; they were the success criteria. (HT)

The two teachers who responded understood a standard to be "what should be achievable" (Participant 7) and "what you are expecting is coherent...not changing in different years...obviously we make allowances for differentiation and individual needs" (Participant 5). A similar conception was held by the QIO:

Well, I'm an associate assessor with HMIE and I'm learning as I go along what they mean by standards. Basically I think where they are coming from is that a standard is almost unique to an individual. That an individual standard of attainment is measured by how much they have progressed from where they have come from, you know from a starting point; when they went into this class they were here and went the left this class they were here, that kind of thing.

At one level, this challenges accepted international literature on the subject of standards whereby externally agreed rubrics define levels to be achieved. However, in many ways this is also symptomatic of the drive, seen across the world, for progression as a marker of success. Whilst the absolutist version of standards might call for simplistic interpretations that countenance 'level checking', a more nuanced, progression-based understanding calls for interpretations based on the difference between levels. In one sense, then, these are somewhat distant interpretations. On another level, however, they connect intimately, for both use externally mandated 
points against which to judge. Clearly, the absolutist version is concerned with proving, whilst the progression-based version is concerned with improving.

\section{Discussion}

From the thematic coding, overarching themes were identified:

- Social Moderation

- Learning, Teaching and the Curriculum

- Relationships

- The Vision for Pupils

\section{Social moderation}

Findings here reflect the recent preponderance of interpretivist research extoling the benefits of moderation as a socio-cultural learning experience in which developing teacher judgement is central (Adie, 2013a; Harlen, 2004; Reid, 2007; Klenowski \&Wyatt-Smith, 2014; Smaill, 2013). Moderation in Scottish primary schools, as communicated in Scottish policy, has also shifted from external moderation through national tests to social moderation (Harlen, Malcolm \& Byrne, 1995; Scottish Government, 2010) although there is to be a shift in this matter back to national testing as of 2017 (The Scottish Government, 2016).

Within the school, and local authority, the moderation discourse changed over time, from an external out-with school event, to a social out-with school event and from 2013 onwards to a social within school process. Whilst national policy gives no prescriptive guidance as to how moderation should be enacted, the school understood social moderation to be a nine stage process split into three moderation 
meetings, time for which is included in the collegiate calendar. This reflects current policy that understands moderation to be a social process in which teachers:

a. plan learning, teaching and assessment

b. check that assessment tasks and activities provide learners with fair and valid opportunities to meet the standards and expectations before assessments are used

c. sample evidence from learners' work and review teachers' judgements

d. agree strengths in learners' performances and next steps in learning

e. provide feedback on teachers' judgements to inform improvements in practices

(Scottish Government, 2010, p. 3)

In the meetings, teachers jointly planned and negotiated what was to be moderated (a). Generated learning intentions and success criteria to use as 'standards', inviting pupils to suggest tasks to be undertaken to meet these (b). Calibrated pupil and teacher success criteria into an assessment rubric (b). Jointly planned assessment tasks and discussed the evidence of learning (c). And, shared the evidence of pupil(s) learning. The data gathered is not suggestive of teachers agreeing next steps for pupils (d) or providing each other with feedback on their judgements (e), despite encouragement from the head teacher to 'challenge each other' with regards to evidence of learning presented. Teaching staff did not agree prior to the moderation of evidence what should be shared at the meetings. This suggests that moderation in the school is functioning primarily as a mechanism for collegiate 'improvement' rather than individual 'accountability' (Maxwell, 2002). 


\section{Learning, Teaching and the Curriculum}

The relationship between learning, teaching, curriculum and moderation is established in theoretical literature (Taylor, 1994). Recently, Klenowksi \& WyattSmith (2014), note that moderation has the potential to alter what teachers do in their classrooms. In Scottish policy teachers are expected to "plan learning, teaching and assessment" when enacting moderation (Scottish Government, 2010, p. 3). The data demonstrate that from 2011 onwards, moderation developed alongside jointplanning, curriculum development, an understanding of skills progression, team teaching and peer observation of practice. All of these elements would become parts of moderation as enacted. Within the school, moderation was a vehicle for developing interdisciplinary project-based learning around themes. Discussions of what should be moderated facilitated the linking of these themes with curriculum areas. In contrast to Hayward et al (2012), this study did not find the issue of 'standards' to be prominent; this may be a reflection of the prevailing national policy discourse of the time vis-à-vis testing. However, teaching staff reported that moderation had affected positively their planning and they were now more 'focused' and 'confident' in what they planned for children, and the expectations they had for achievement within the curriculum levels.

An international skills agenda (OECD, 2012) and national level (BtC4) is evident. Recent literature on the positioning of knowledge in Curriculum for Excellence suggests this may be problematic, as the place for knowledge in the school's moderation process is not clearly articulated (Priestley \& Sinnema, 2014). The national policy agenda of assessing progress and achievement correlates with the enactment of moderation in the school, evidenced by the production of progression 
rubrics and the discussion of progress in relation to individual children (Educationscotland.gov.uk, 2015). A shared understanding of teaching, learning and curriculum in the school and of what 'quality' is with respect to these has underpinned the understanding and enactment of moderation.

\section{Relationships}

Effective relationships between the local authority and Education Scotland; the school and the local authority; the school and other schools and between teachers within the school were all factors that contributed to building an understanding of moderation and of enacting moderation as a process. The Head Teacher's effective leadership of moderation meetings was a key factor in enacting moderation in the school; all teachers reported that they felt supported, something which Hipkins \& Robertson (2011) cite as vital to the moderation process. The Head established a vision of distributed leadership underpinned by dialogue about teaching and learning (cf. Priestley et al, 2011; Grainger et al, 2015). The moderation meetings were enacted as a 'community of practice' (Lave and Wenger, 1991) in which all staff contributed in a way which was underpinned by a strong sense of shared values, seeing themselves as 'family' (Klenowski \& Wyatt-Smith, 2014). There was a positive attitude toward collaborative practice and sustained motivation in the school to engage in 'community building' (Bloxham, Hughes \& Adie, 2015). The importance of teacher leadership and ownership of the moderation process was also a key finding evidenced by a member of the teaching staff acting as a moderation facilitator. The teaching staff were positive about what they saw as 'one of them' taking forward moderation and this was a contributing factor to their 'buy in'. According to Grainger et al (2015: 11) 'consistency of teacher judgements is most enhanced by the 
development of close relationships between team members, built over time' a finding consistent with this study.

\section{The Vision for Pupils}

This research identified that the school had a shared vision for pupils that had influenced the way moderation was enacted. Firstly there were discourses of equity whereby the school wanted children to achieve and be judged fairly according to their potential; as Adie et al (2013) note, this aids the moderation and teachinglearning process. Such judgements led moderation, particularly in primary 4 to 7 , to be enacted in multi-age and multi-stage groups where children were not being judged against a chronological 'norm'.

Secondly, staff were conscious of enabling pupils to have ownership of their learning in line with the Curriculum for Excellence design principle 'personalisation and choice'. The calibration of pupil success criteria with teacher success criteria was an important element of enacted moderation with the head teacher 'determined' pupils would be involved in creating the assessment rubric and tasks. Whilst ownership rather than calibration was the goal, the effect of involving pupils in the process of moderation was one of calibration between pupils and teachers concerning assessment criteria and how success was judged (cf. Hattie, 2013; Alexander, 2013). Teaching staff reported this had made pupils more independent and effective at self-assessing, more able to speak about their learning and increasingly, with practice, better at framing success criteria. These findings concur with Hattie (2013) concerning calibration having a positive influence on pupil self-regulation and metacognition. 


\section{Conclusion}

Within current Scottish educational policy, moderation is understood to be an effective form of professional learning and accountability (Scottish Government, 2010). The main feature of such a system is one of ensuring educational success for pupils through professional development for teachers. The moderation process centres on the ideals of participation and close links between learning, teaching and assessment. One feature of the Scottish system is the use of moderation as an activity which seeks to develop 'tasks and activities which provide learners with fair and valid opportunities to meet the standards and expectations' required of them (Scottish Government, 2010: 3). Evidence from learners' work is to be shared and discussed along with a review of teacher judgements. In many respects, such a position adopts a moderation-as-social-process approach whereby a socio-cultural community of practice is engendered (Klenowski \& Wyatt-Smith, 2014). Such an approach seeks to locate moderation as a professional learning activity (Adie et al, 2013).

Within the case study school, the understanding of moderation evolved from an external event to a social process. Moderation came to be understood through a whole school process underpinned by professional dialogue. At its core, such processes were believed to require both leadership and teacher ownership.

Such matters were supported through the ways in which moderation enactment was achieved. The moderation process enacted in the study spanned nine stages, including three meetings over a period of three months. The focus for the meetings 
was: to decide on what was to be moderated and create learning intentions; to create a progression rubric of success criteria for each curriculum level; and to discuss the evidence of learning generated in the process of teaching. The process was led by the head teacher and a moderation facilitator and relationships within and out-with the school were a contributing factor to the school's success in enacting moderation. The data here shows that moderation was enacted as a 'project' often with an overarching theme (for example enterprise or leadership). The focus of staff when discussing what to moderate was on skills rather than knowledge. In this regard learning intentions and success criteria functioned as the 'standard' around which both staff and pupils calibrated their judgement about achievement. Understanding progression from early to third level of the curriculum was a central aim of the moderation process described by the head teacher as the 'value added' at each level.

In an attempt to conceptualise moderation with regard to the results of this study and wider literature, we offer figure 3 as a representation. This consists of two perpendicular continua that together form 4 quadrants. The continua are represented by arrows to indicate that they are indicative of a spectrum of possibilities. Although the descriptions for each quadrant might be read as bounded, they are indicative of positons within the relative areas indicated. 


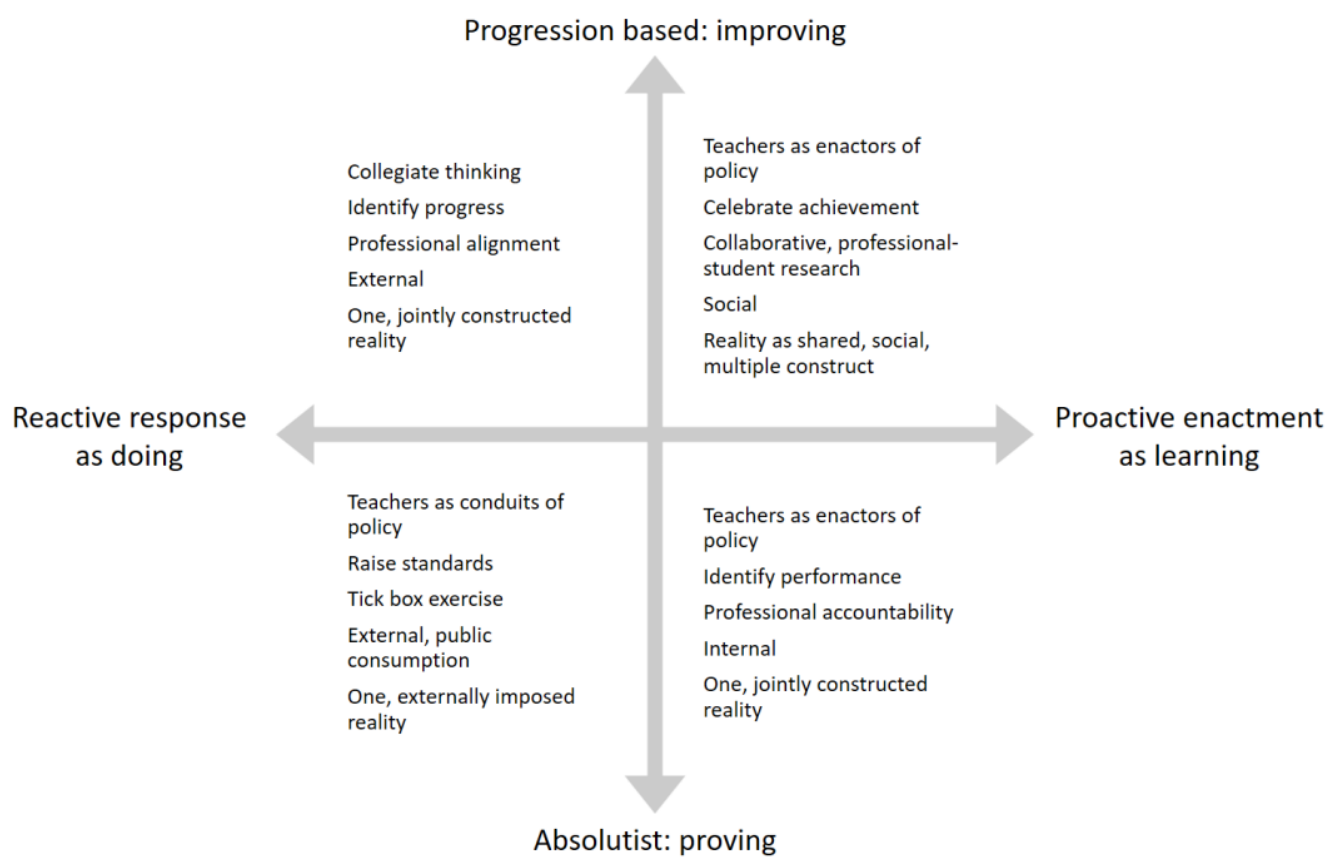

Figure 3: moderation typology

The horizontal continuum represents an interplay between, on the one extreme, mechanisms that seemingly respond to policy, whilst at the other, mechanisms which seemingly enact policy. Here enactment is taken to be 'an understanding that policies are interpreted and 'translated' by diverse policy actors in the school environment, rather than simply implemented' and that, consequently 'putting policies into practice is a creative, sophisticated and complex process that is always also located in a particular context and place' (Braun, Maguire and Ball, 2010: 549). The vertical axis represents the interplay between, on the one hand, mechanisms that are based on moderation as a credentialising activity; that is to say moderation as proving the value or worth of an individual or group relative to a set of standards. The other end counters this and represents moderation as a means to measure improvement. 
Within this schematic can be discerned five elements for consideration. Firstly, the relative position against the axes identifies the ways in which teachers are oriented as actors in the moderation process; at the one end are mechanisms that point to teachers as conduits of policy, and at the other, teachers as enactors of policy. Secondly, the aims of moderation. Here can be seen the distinction between moderation as a mechanism to validate and moderation as a means to learn. Thirdly, the relationship between the professional and the state including the standing they have as professionals within the public sphere is indicated by, on the one hand, performative accounts and on the other wider ideas of professionalism including collaborative working. Fourthly, the locus for the moderation be that external or internal. Finally, the exemplification of epistemological matters: the construction of knowledge and its perceived effect come to the fore within the bounded case of moderation as a form of social activity. Here a distinction can be made between moderation that seeks to validate one, external reality or moderation that recognises the contextualised nature of educational knowledge and its relationship with and to forms of knowing.

Whilst work towards the upper right quadrant seemed part of the aims for the school, how this was realised was also noteworthy. Clearly, in line with trends in the literature, moderation in the school has moved from being externally focused to socially mediated. The data suggests that the participants viewed moderation as a 'community of practice' and as a form of socio-cultural learning. The discourses of moderation in the school focused on 'equity' for learners with regards to: expectations for children not being bound by year group norms; community building through moderation, regarding it as having increased the amount of time spent 
working together informally; and professional learning, particularly in relation to skills progression, planning and curriculum development.

With regard to the purpose of moderation in current policy as communicated through BtC5, data here showed that teachers engaged in planning, task development and the collation of evidence for review. The data gathered is not suggestive of teachers agreeing next steps for pupils or providing each other with feedback on their judgements. In the absence of these latter two points, the dual purpose of accountability and professional learning, as communicated in policy, was not fully realised. Teaching staff did not agree prior to moderation meetings the evidence around which they would feed back on their professional judgements. The evidence presented was not systematically analysed for pupils' next steps. This suggests that the purpose of moderation in the school is functioning primarily as a mechanism for collegiate improvement and professional learning, strongly aligned to curriculum development and planning for skills.

However, this latter position must be considered further. Since the announcement by the Scottish Government that national testing is to return (The Scottish Government, 2016), questions can now be asked about the place for activities which concentrate on professional development and collegiate working but which do not turn to matters of 'effectiveness' and 'improvement' as measured by test scores. The 'regime of truth' often sanctioned by testing in other countries, for example England and Australia, often directs professional activity towards mechanistic processes designed to uplift educational attainment. Whether this will occur in Scottish schools remains 
to be seen. It may well be that the process remains one of a community of practice; time will tell.

\section{References}

Adelman, C., Jenkins, D., \& Kemmis, S. (1980). Rethinking case study. Notes from the second Cambridge conference In Simons, H. (1980). Towards a science of the singular. Norwich [Norfolk]: Centre for Applied Research in Education, University Of East Anglia.

Adie, L. (2013a). The development of teacher assessment identity through participation in online moderation. Assessment in Education. Principles, Policy \& Practice, 20(1), 91-106.

Adie, L. (2013b). The development of shared understandings of assessment policy: travelling between global and local contexts. Journal of Education Policy, 28(1), $1-14$.

Adie, L., Lloyd, M., \& Beutel, D. (2013). Identifying discourses of moderation in higher education. Assessment \& Evaluation in Higher Education, 38(8), 968977.

Allal, L. (2013). Teachers' professional judgement in assessment: a cognitive act and a socially situated practice. Assessment in Education: Principles, Policy \& Practice. 20(1), 20-34.

Alexander, P., A. (2013). Calibration: What is it and why it matters? An introduction to the special issue on calibrating calibration. Learning and Instruction, 24, 1-3.

Andrews, R. (2003). Research questions. London: Continuum.

Ball, S. J. (2008). The education debate. Bristol: Policy Press.

Ball, S. J. (2015). Education, governance and the tyranny of numbers. Journal of 
Education Policy, 30(3), 299-301.

Bassett, B., R. (2010) Iterative in Mills, A. J., Durepos, G., \& Wiebe, E. (Eds.) (2010).

Encyclopedia of case study research. Thousand Oaks, CA: SAGE Publications

Bassey, M. (1999). Case study research in educational settings. Buckingham

[England]: Open University Press.

Bereiter, C. (2002). Education and mind in the knowledge age. Mahwah, N.J.: L.

Erlbaum Associates.

Black, P. (2001). Dreams, Strategies and Systems: Portraits of assessment past, present and future. Assessment In Education: Principles, Policy \& Practice, 8(1), 65-85.

Black, P., Harrison, C., Hodgen, J., Marshall, B., \& Serret, N. (2010). Validity in teachers' summative assessments. Assessment in Education: Principles, Policy \& Practice, 17(2), 215-232.

Bloxham, S. (2009). Marking and moderation in the UK: false assumptions and wasted resources. Assessment \& Evaluation in Higher Education, 34(2), 209220.

Bloxham, S., Hughes, C., \& Adie, L. (2015, June). What's the point of moderation? A discussion of the purposes achieved through contemporary moderation practices. Assessment \& Evaluation in Higher Education, 1-16.

Braun, A., Maguire, M. \& Ball, S.J. (2010). Policy enactments in the UK secondary school: examining policy, practice and school positioning. Journal of Education Policy, 25(4), 547-560.

Broadfoot, P. (1996). Education, assessment, and society. Buckingham: Open University Press. 
Brookhart, S. M. (2013). The use of teacher judgement for summative assessment in the USA. Assessment in Education: Principles, Policy \& Practice, 20, 69-90.

Brown, G. T. L. (2004). Teachers' conceptions of assessment: implications for policy and professional development. Assessment in Education: Principles, Policy \& Practice, 11(3), 301-318.

Clough, P. \& Nutbrown, C. (2002). A student's guide to methodology. London: SAGE Publications.

Collins, S., Reiss, M., \& Stobart, G. (2010). What happens when high-stakes testing stops? Teachers' perceptions of the impact of compulsory national testing in science of 11-year-olds in England and its abolition in Wales. Assessment in Education: Principles, Policy \& Practice, 17(3), 273-286.

Connolly, S., Klenowski, V., \& Wyatt-Smith, C. M. (2012). Moderation and consistency of teacher judgement: teachers' views. British Educational Research Journal, 38(4), 593-614.

Cooksey, R. W., Freebody, P., \& Wyatt-Smith, C. (2007). Assessment as Judgmentin-Context: Analysing how teachers evaluate students' writing 1. Educational Research and Evaluation, 13(5), 401-434.

Creswell, J. (2011). Research design. Thousand Oaks, Calif.: Sage Publications. Cumming, J. J., \& Maxwell, G. S. (2004). Profiles of educational assessment systems worldwide. Assessment in Education: Principles, Policy \& Practice, 11(1), 89-108.

Datnow, A. (2014). Data-Driven Leadership. Jossey-Bass.

Educationscotland.gov.uk, (2015). Assessing progress and achievement Assessment - Learning and teaching. [online] Retrieved from: 
http://www.educationscotland.gov.uk/learningandteaching/assessment/progres sandachievement/. Accessed 1 Jun. 2015.

Elger, T (2010) Contextualization In A. J. Mills, G. Durepos \& E. Wiebe (Eds), (2010). Encyclopedia of case study research. Los Angeles: SAGE Publications.

EIS. (2012). Primary \& Early Years Bulletin. EIS.

Filer, A. (1995). Teacher Assessment: social process and social product. Assessment in Education: Principles, Policy \& Practice, 2(1), 23-38.

Fullan, M. (2001). The new meaning of educational change. New York: Teachers College Press.

Gillham, B. (2000). Case study research methods. London: Continuum.

Gillham, B. (2000a). The research interview. London: Continuum.

Gillham, B. (2005). Research interviewing. Maidenhead: Open University Press.

Gillies, D. (2008). Developing Governmentality: conduct and education policy. Journal of Education Policy, 23(4), 415-427.

Gipps, C. (2012). Beyond testing. London: Falmer Press.

Gill, T., \& Bramley, T. (2013). How accurate are examiners' holistic judgements of script quality? Assessment in Education: Principles, Policy \& Practice, 20(3), 308-324.

Gubrium, J. F. \& Holstein, J. A. (2002). Handbook of interview research. Thousand Oaks, Calif.: Sage Publications.

Greene, J. C. (2010). Knowledge accumulation. In: Luttrell, W. eds. (2010). Qualitative educational research: readings in reflexive methodology and transformational practice. New York: Routledge, pp. 63-77. 
Gov.scot. (2015). Postcode Lookup - Argyll \& Bute. Retrieved from http://www.gov.scot/Topics/Statistics/SIMD/PostcodeLookupArgyllBute.

Grainger, P., Adie, L., \& Weir, K. (2015, June). Quality assurance of assessment and moderation discourses involving sessional staff. Assessment \& Evaluation in Higher Education, 1-12.

Habermas, J. (1975). Legitimation crisis. Boston: Beacon Press.

Hammersley, M., \& Traianou, A. (2012). Ethics in qualitative research. Thousand Oaks, Calif.: SAGE Publications.

Harlen, W. (2004, March). A systematic review of the evidence of reliability and validity of assessment by teachers used for summative purposes. Research Evidence in Education Library, 1-179.

Harlen, W. (2007). Assessment of learning. Los Angeles, CA.: SAGE Publications. Harlen, W., Malcolm, H. C., \& Byrne, M. (1995). Teachers' Assessment and National Scotland : roles and relationships. Assessment in Education: Principles, Policy \& Practice, 2(2), 37-41.

Harlen, W. \& Schlapp, U. (1998). Literature Reviews. SCRE Spotlight Paper no. 71. Harris, L. R., \& Brown, G. T. L. (2009). The complexity of teachers' conceptions of assessment: tensions between the needs of schools and students. Assessment in Education: Principles, Policy \& Practice, 16(3), 365-381.

Hattie, J. (2013). Calibration and confidence: Where to next? Learning and Instruction, 24, 62-66.

Hay, P. J., \& Macdonald, D. (2008). (Mis)appropriations of criteria and standardsreferenced assessment in a performance-based subject. Assessment in Education: Principles, Policy \& Practice, 15(2), 153-168. 
Hayward, L. (2004). Ruffling the calm of the ocean floor: merging practice, policy and research in assessment in Scotland. Oxford Review of Education, 30(3), 397415.

Hayward, L. (2007). Curriculum, pedagogies and assessment in Scotland: the quest for social justice. 'Ah kent yir faither'. Assessment in Education: Principles, Policy \& Practice, 14(2), 251-268.

Hayward, L., Menter, I., Baumfield, V., Daugherty, R., Akhtar, N., Doyle ... Arthur, L. (2012). Assessment at Transition Report. Glasgow: University of Glasgow. Heldsinger, S. a., \& Humphry, S. M. (2013). Using calibrated exemplars in the teacher-assessment of writing: an empirical study. Educational Research, 55(3), 219-235.

Hipkins, R., \& Robertson, S. (2011). Moderation and Teacher Learning: What can research tell us about their interrelationships? New Zealand Council for Educational Research: Wellington

Hume, A., \& Coll, R. K. (2009). Assessment of learning, for learning, and as learning: New Zealand case studies. Assessment in Education: Principles, Policy \& Practice, 16(3), 269-290.

Jones, B. E. (1997). Comparing Examination Standards: is a purely statistical approach adequate? Assessment in Education: Principles, Policy \& Practice, 4(2), 249-264.

Kemmis, S. (1980) The imagination of the case and the invention of the study. In $\mathrm{H}$. Simons. (1980). Towards a science of the singular. Norwich [Norfolk]: Centre for Applied Research In Education, University Of East Anglia. 
Klenowski, V. (2013a). Towards improving public understanding of judgement practice in standards-referenced assessment: an Australian perspective. Oxford Review of Education, 39(1), 36-51.

Klenowski, V. (2013b). Investigating the complexity of judgement practice.

Assessment in Education: Principles, Policy \& Practice, 20(1), 1-4.

Klenowski, V., \& Wyatt-Smith, C. (2012). The impact of high stakes testing: the Australian story. Assessment in Education: Principles, Policy \& Practice, 19(1), $65-79$.

Klenowski, V. \& Wyatt-Smith, C. (2014). Assessment for education. London: Sage. Kumar, R. (2005). Research methodology. London: SAGE.

Lave, J. and Wenger, E. (1991). Situated learning. Cambridge [England]: Cambridge University Press.

Lee, R. M. (2000). Unobtrusive methods in social research. Buckingham [England]: Open University Press.

Lincoln, Y. S. \& Guba, E. G. (1985). Naturalistic inquiry. Beverly Hills, Calif.: Sage Publications.

Lingard, B., Martino, W., \& Rezai-Rashti, G. (2013). Testing regimes, accountabilities and education policy: commensurate global and national developments. Journal of Education Policy, 28(5), 539-556.

Linn, R. L. (1993). Linking Results of Distinct Assessments. Applied Measurement in Education, 6(1), 83-102.

MacCann, R. G., \& Stanley, G. (2010). Classification consistency when scores are converted to grades: examination marks versus moderated school assessments. Assessment in Education: Principles, Policy \& Practice, 17(3), 255-272. 
Maxwell, G. (2002). Moderation of Teacher Judgments in Student Assessment. Brisbane.

Meadmore, D. (1995). Linking Goals of Governmentality with Policies of Assessment. Assessment in Education: Principles, Policy \& Practice, 2(1), 922.

Merriam, S. (1988). Case study research in education. San Francisco: Jossey-Bass. Miles, M., \& Huberman, A. (1994). Qualitative data analysis. Thousand Oaks: Sage Publications.

Murray, J. (2014). Critical Issues Facing School Leaders Concerning Data: Informed Decision Making. The Professional Educator, 38(1), 1-8.

Miles, M. B. \& Huberman, A. M. (1994). Qualitative data analysis. Thousand Oaks: Sage Publications.

Mislevy, R. J. (2006). Issues of Structure and Issues of Scale in Assessment from a Situative/Sociocultural Perspective (Vol. 1522). Los Angeles, California.

Mislevy, R. J., Haertel, G., Cheng, B. H., Ructtinger, L., DeBarger, A., Murray, E., Vendlinski, T. (2013). A "conditional" sense of fairness in assessment. Educational Research and Evaluation, 19(2-3), 121-140.

Newby, P. (2010). Research methods for education. Harlow, England: Pearson Education Ltd.

Organisation for Economic and Cultural Development (2012). Better Skills, Better Jobs, Better Lives: A Strategic Approach to Skills Policies. Paris: Author.

Olssen, M., \& Peters, M. (2005). Neoliberalism, higher education and the knowledge economy: from the free market to knowledge capitalism. Journal of Education Policy, 20(3), 313-345. 
O’Neill, O. (2013). Intelligent accountability in education. Oxford Review of Education, 39(1), 4-16.

Orr, S. (2007). Assessment moderation: constructing the marks and constructing the students. Assessment \& Evaluation in Higher Education, 32(6), 645-656.

Ozga, J. et al (2009). ECRP05: Governing by Numbers : Data and Education Governance in Scotland and England: Full Research Report ESRC End of Award Report, RES-000-23-1385. Swindon: ESRC

Ozga, J. (2012).Comparison as a Governing Technology: The Case of PISA. Research Intelligence 1(19), 18-19.

Priestley, M., Miller, K., Barrett, L., \& Wallace, C. (2011). Teacher learning communities and educational change in Scotland: the Highland experience. British Educational Research Journal, 37(2), 265-284.

Priestley, M., \& Sinnema, C. (2014). Downgraded curriculum? An analysis of knowledge in new curricula in Scotland and New Zealand. Curriculum Journal, $25(1), 50-75$.

Reid, L. (2007). Teachers talking about writing assessment: valuable professional learning? Improving Schools, 10(2), 132-149.

Roberts-Holmes, G. (2014). The "datafication" of early years pedagogy: "if the teaching is good, the data should be good and if there's bad teaching, there is bad data". Journal of Education Policy, 30(3), 1-13.

Sadler, D. R. (1992). Expert Review and Educational Reform: The Case of Student Assessment in Queensland Secondary Schools. Australian Journal of Education, 36(3), 301-317. 
Sadler, D. R. (2013). Assuring academic achievement standards : from moderation to calibration. Assessment in Education. Principles, Policy \& Practice, 20(1), 519.

Sapsford, R. \& Jupp, V. (2006). Data collection and analysis. London: SAGE Publications In Association With The Open University.

Schram, T., \& Schram, T. (2006). Conceptualizing and proposing qualitative research. Upper Saddle River, N.J.: Pearson Merrill Prentice Hall.

Scotland, T. (2014). EIS Highlights Continuing Pressures Around CfE. Retrieved from: http://www.eis.org.uk/public.asp?id=2553\&parentid=2\&dbase=2. Accessed: 20 Mar 2014.

Scottish Government. (2008). Curriculum for excellence building the curriculum 3: a framework for learning and teaching. Edinburgh: Author.

Scottish Government. (2009a). Assessment for Curriculum for Excellence Strategic Vision Key Principles. Edinburgh: Author.

Scottish Government. (2009b). Curriculum for excellence building the curriculum 4: skills for learning, skills for life and skills for work. Edinburgh: Author.

Scottish Government. (2010). Building the curriculum 5 a framework for assessment: quality assurance and moderation. Glasgow: APS.

Scottish Government. (2013). Curriculum for excellence working group on tackling bureaucracy. Edinburgh: Author.

Scottish Government (2016) National improvement Framework for Scottish Education: achieving excellence and equity, Edinburgh: Author. Smaill, E. (2013). Moderating New Zealand's National Standards: teacher learning and assessment outcomes. Assessment in Education: Principles, Policy \& Practice, 20(3), 250-265. 
Sprague, J. (2010). Seeing through science: Epistemologies. In W. Luttrell (Ed.), Qualitative educational research: Readings in reflexive methodology and transformative practice. New York, NY: Routledge.

Stake, R. E. (1995). The art of case study research. Thousand Oaks: Sage Publications.

Stark, R. (1998). Practitioner Research: the Purposes of Reviewing the Literature within an Enquiry, SCRE Spotlight Paper no. 67.

Strathclyde, University of (2013). Code of Practice on Investigations Involving Human Beings Sixth Edition (pp. 1-49). Glasgow: Author.

Swanborn, P. G. (2010). Case study research. Los Angeles: SAGE.

Tatto, M. (2007). Reforming teaching globally. Didcot: Symposium Books.

Taylor, C. (1994). Assessment for Measurement or Standards: The Peril and Promise of Large-Scale Assessment Reform. American Educational Research Journal, 31(2), 231-262.

The World Bank. (2010). Stepping up Skills For more jobs and higher productivity. Washington: Author.

Thomas, G. (2011). How to do your case study. Los Angeles, Calif.: SAGE. www.educationscotland.gov.uk,. (2015). Assessment. Retrieved from: http://www.educationscotland.gov.uk/learningteachingandassessment/assessm ent/index.asp.

Wenger, E. (1998). Communities of practice. Cambridge, U.K.: Cambridge University Press.

Wiliam, D. (2011). Embedded formative assessment. Bloomington, IN: Solution Tree Press. 
Wilson, M. (1992). Educational Leverage from a Political Necessity: Implications of New Perspectives on Student Assessment for Chapter 1 Evaluation. Educational Evaluation and Policy Analysis, 14(2), 123-144.

Wyatt-smith, C., \& Klenowski, V. (2013). Explicit, latent and meta-criteria: types of criteria at play in professional judgement practice. Assessment in Education: Principles, Policy \& Practice, 20(1), 35-52.

Yin, R. K. (2003). Applications of case study research. Thousand Oaks: Sage Publications.

Young, E. (2005). Assessment for Learning: embedding and extending. Retrieved from https://www.educationscotland.gov.uk/Images/Assessment\%20for\%20Learning \%20version\%202vp tcm4-385008.pdf. Accessed 17/2/2015. 